\title{
Ekspresi Linguistik Tanaman Jagung sebagai Kearifan Lokal Penutur Bahasa Tombulu
}

\author{
Djeinnie Imbang \\ imbangdjeinnie@gmail.com \\ Leika M.V. Kalangi \\ leikamvk@17gmail.com \\ Olga Karamoy \\ karamoyolga1@gmail.com
}

\begin{abstract}
This research is focused on the anthropolinguistic study which is to observe the correlation between language and socio-cultural aspects based on the ethnicity of a certain linguistic community. This research aims to (a) identify and classify the linguistic forms regarding of maize in Tombulu language; and to (b) describe the forms of local wisdom pertaining maize.

In this research, we used qualitative-descriptive method which is a form of problem-solving procedure that endeavors to describe the condition of research objects in the current times based on the observed empirical facts. The techniques and instruments for the data collection are through observation and in-depth interview. The interview is done in order to obtain the linguistic data that are in the form of verbal expressions and local wisdoms which are possessed by the farmer from Tombulu speaker. As for the data analysis, we used an anthropolinguistic analysis that focuses on the linguistic data without neglecting the local wisdoms that are inherent to the observed society. Thus, it is found that the linguistic form regarding to maize such as words, phrases, idioms, and local wisdoms are mapalus and cosmic knowledge relating to the crop.
\end{abstract}

Keywords: linguistic expression, Tombulu language, local wisdom

\section{Abstrak}

Penelitian ini berfokus pada kajian antropolinguistik, yaitu menyelidiki hubungan antara bahasa dan aspek-aspek sosio-kultural berdasarkan etnisitas dari suatu guyuban bahasa yang bertujuan: 1) mengidentifikasi dan mengklasifikasi bentuk-bentuk ekspresi linguistiktanaman jagung dalam bahasa daerah Tombulu;2) mendeskripsikan bentuk-bentuk kearifan lokal dalam kaitannya dengan tanaman pangan, lebih khusus tanaman jagung.

Dalam penelitian ini digunakan metode deskriptif kualitatif, yaitu prosedur pemecahan masalah yang diselidiki dengan menggambarkan atau melukiskan keadaan objek penelitian pada saat sekarang berdasarkan fakta-fakta yang tampak sebagaimana adanya. Teknik dan alat pengumpulan data diperoleh melalui observasi langsung dan wawancara.Wawancara digunakan untuk mendapatkan data kebahasaan yang merupakan ekspresi verbal dan kearifan lokal yang dimiliki oleh petani penutur bahasa Tombulu.Analisis data digunakan model analisis antropolinguistik yang menitikberatkan pada data kebahasaan tanpa meninggalkan kearifan lokal yang melekat pada masyarakat. Dengan demikian telah ditemukan bentuk ekspresi linguistik tanaman jagung, seperti kata, frase, dan idiomserta kearifan lokal, antara lain mapalus dan pengetahuanastronomi dalam kaitan dengan tanaman.

Kata Kunci: Ekspresi Linguistik, Bahasa Tombulu, Kearifan Lokal 


\section{PENDAHULUAN}

Dalam siklus kehidupan manusia, hubungan antarmanusia tidak pernah lepas dari bahasa. Bahasa sebagaimana terwujud dalam bentuk kata-kata, kalimat, dan kesatuan gagasan merupakan objektivasi dari kesadaran kita akan kenyataan, baik kenyataan lahiriah maupun kenyataan batiniah. Komunitas antara dua orang atau lebih merupakan proses pertukaran hasilhasil objektivasi dan dalam pertukarannya, gagasan-gagasan bukan hanya salingdiungkapkan melainkan diperluas, diperdalam, dan dipertegas maknanya lewat proses penafsiran timbal balik. (Koentjaraningrat 1990; Foley 1997; Duranti 2001)

Setiap kebudayaan di dunia dapat dikenal, antara lain melalui bahasa. Hubungan bahasa dan kebudayaan sangat erat, bahkan sering diibaratkan seperti hubungan dua sisi mata uang.Bahasa mempunyai hubungan dengan kebudayaan karena bahasa merupakan petunjuk kebudayaan.Seseorang tidak dapat memahami bahasa dan menilai kebudayaan tanpa memahami keduanya. Demikian pula, pendapat Sapir (1921) kebudayaan adalah apa yang dilakukan dan dipikirkan oleh suatu masyarakat sedangkan bahasa adalah bagaimana orang berpikir.

Di Minahasa bermukim kelompok etnik yang terbagi menurut lokalitas pemakai bahasa, yaitu empat kelompok etnik besar: Tombulu, Tonsea, Tondano, Tontemboan dan empat kelompok etnik kecil: Tonsawang, Pasan/Ratahan, Ponosakan dan Bantik (Renwarin, 2007:13). Dari kelompok etnis di atas, yang menjadi objek penelitian dibatasi pada lokalitas pemakai bahasa Tombulu, lebih khusus pemakai bahasa Tombulu yang berdomisili di Kelurahan Pangolombian.

Kelurahan Pangolombian merupakan salah satu kelurahan yang ada di Kecamatan Tomohon Selatan Kota Tomohon. Kota Tomohon letaknya kira-kira 25 km dari kota Manado, dari aspek bahasa membawa pengaruh yang signifikan bagi kelangsungan bahasa Tombulu. Bahasa Tombulu hampir tidak terdengar lagi digunakan oleh generasi muda dewasa ini. Bahkan, usia di bawah 50 tahun hampir tidak dapat berbahasa secara aktif. Adanya keprihatinan atas kelangsungan bahasa ini, di tahun 2015 Pemerintah Kota Tomohon melaksanakan lomba pidato berbahasa Tombulu. Di lain pihak, pemerhati bahasa melakukan aktivitas pendokumentasian melalui terjemahan cerita rakyat berbahasa Tombulu dan terjemahan alkitab bahasa Tombulu yang dilakukan oleh yayasan UKIT.

Penelitian bahasa Tombulu sudah dilakukan antara lain oleh Tim Peneliti Fakultas Sastra tahun 1978 dengan judul Struktur Bahasa Minahasa (Tombulu, Tonsea, Tondano), Sahulata 
(1993) Struktur Bahasa Tombulu, Karouw (2009) Makna dan Peran Kata-Kata Kerabat Masyarakat Pemakai bahasa Tombulu, Makalew (1995) Fonologi Bahasa Tombulu. Penelitianpenelitian berkaitan dengan struktur bahasa pun sudah cukup lama dilakukan dan belum semua terpublikasi, apalagi dalam jurnal 5 tahun terakhir.Umumnya, data bahasa yang terdeskripsi dalam penelitian terdahulu mengabaikan kosakata bidang pertanian. Peneliti-peneliti yang mengambil objek penelitian bahasa dari bidang makrolinguistik, seperti bahasa Tombulu yang terpublikasi dari hasil penelusuran, terutamaonline(daring) ternyata pada umumnya para peneliti ini berlatar belakang bidang IT ( Fakultas Teknik) sehingga mereka merancang aplikasi perkamusan, baik dalam web maupun berbasis android, seperti yang dilakukan oleh Wahyudi (2016) Translator Real-Time Bahasa Indonesia-Tombulu (cogito.unklab.ac.id), Sageroki (2016) Aplikasi Terjemahan Bahasa Indonesia-Bahasa Tombulu (repository.polimdo.ac.id), dan Tenda (2016) Rancang Bangun Kamus Minahasa (Tombulu)-Indonesia Berbasis Web. (e-jurnal Sariputra, Juni 2016 vol3).Ketika aplikasi ini diunduh ternyata kosakata yang terdaftar masih sangat kurang, berkisar 140 kosakata saja dan kosakata tersebut masih sangat kurang atau hampir tidak ditemukan berkaitan dengan tanaman (pertanian). Oleh karena itu, sangat tepat apabila penelitian ini dilakukan karena dapat menambah perbendaharaan kosakata dalam kamus Tombulu yang aplikasinya sudah dan dibuat oleh para mahasiswa yang studi di Fakultas Teknik.Kerjasama penelitian multibidang yang disaran-sarankan saat ini dapat teraplikasikan sesuai tuntutan, dalam kaitan dengan pemertahanan bahasa (untuk kajian bahasa).Demikian pula, Rawis (2016) sudah melakukan penelitian kearifan lokal petani milu, tetapi dalam kajian Antropologi dan penelitiannya dibatasi khusus di Desa Tondegesan Kabupaten Minahasa yang pemakai bahasa Tontemboan.

Penelitian terdahulu yang dipaparkan di atas memberi arah penelitian ini, yang berfokus pada kajian antropolinguistik, yaitu menyelidiki hubungan antara bahasa dan aspek-aspek sosiokultural berdasarkan etnisitas dari suatu guyuban bahasa. Selain identifikasi dan klasifikasi jenis tanaman dari aspek bahasa daerah.

Petani tradisional masih menggunakan bahasa Tombulu dalam aktivitas keseharian mereka.Bahkan di antara mereka masih menganut folosofi yang diangkat dari ungkapan wa'u na'e, wa'u ngekeroan 'basah kaki, basah kerongkongan'. Basah kaki dianalogikan dengan keluar rumah untuk bekerja, basah kerongkongan dianalogikan dengan tersedianya makanan untuk dimakan.

Setiap bahasa yang ada di Minahasa mempunyai keunikan sendiri, demikian pula dengan bahasa daerah Tombulu dalam lingkup pertanian tanaman jagung.Banyak bentuk-bentuk leksikal yang tidak diketahui lagi oleh generasi saat ini.Komunitas petani sebagai subjek penelitian ini 
mempunyai pengetahuan-pengetahuan lokal yang digunakan untuk menata kehidupan sosial mereka.Hal seperti itu disebut sebagai kearifan lokal.

Kearifan lokal sering dipadankan dengan kata indigenous knowledge, yaitu kebiasaan, pengetahuan, persepsi, norma, dan kebudayaan yang diapatuhi bersama suatu masyarakat (lokal) dan hidup turun-temurun. Pengetahuan lokal merupakan segala bentuk pengetahuan dan perlakuan masyarakat lokal yang umumnya diturunkan secara lisan dari satu generasi ke generasi lain sehingga jarang didokumentasikan (Sibarani, 2012)

Kearifan lokal adalah perangkat pengetahuan pada suatu guyuban (komunitas) baik yang berasal dari generasi-generasi masa lampau maupun dari pengalamannya berhubungan dengan lingkungan dan masyarakat lain untuk menyelesaikan persoalan atau kesulitan yang dihadapi (Duranti, 2001). Demikian juga, dikatakan bila kita menelusuri kembali kearifan-kearifan itu maka mau-tidak-mau kita harus meninjau kembali paradigma pembangunan yang melahirkan kebijakan-kebijakan dari atas (top down-the government knows best what a community needs). Jadi, dimulailah usaha untuk memberdayakan masyarakat dengan memperhatikan kemampuankemampuan yang ada, yaitu kearifan lokal untuk menunjang upaya mewujudkn kesejahteraan sosial yang lebih sesuai dengan kebutuhan masyarakat dan lebih lestari karena diterima dan diterapkan dalam kehidupan. Jadi diperlukan revitalisasi kearifan lokal untuk mencapai kesejahteraan sosial yang diinginkan.

Berdasarkan uraian di atas, maka tujuan dilakukan penelitian ini adalah

1) mengidentifikasi dan mengklasifikasi bentuk-bentuk ekspresi linguistiktanaman jagungdalam bahasa daerah Tombulu;

2) mendeskripsikan bentuk-bentuk kearifan lokal dalam kaitan pemertahanan bahasa dan budaya.

\section{METODE PENELITIAN}

Penelitian ini merupakan penelitian kualitatif karena tujuannya menginventaris dan mendokumentasikan bentuk ekspresi linguistik yang digunakan oleh komunitas petani Tombuludi Kelurahan Pangolombian termasuk kearifan lokal yang dimiliki mereka berkaitan dengan tanaman.

Pengumpulan data dilakukan dengan pengamatan dan wawancara.Pengamatan penting dilakukan untuk mendapatkan data berkenan dengan kondisi obyektif petani tanaman jagung di lapangan. Wawancaradilakukan terutama kepada informan petani jagungyang dapat berbahasa Tombulu dan memiliki pengetahuan astronomi tentang tanaman/menanam.Dilanjutkan dengan analisis dalam perspektif antropolinguistik. 


\section{Hasil Penelitian}

A. Bentuk Ekspresi Tanaman Jagung/tandei/dalam tahapan-tahapannya

Berikut ini dideskripsikan kosa kata yang ditemukan dalam wacana sistem bertani jagung yang selanjutnya dibuat pengelompokkan kata, frasa, dan klausa berdasarkan data yang diperoleh.

\section{Membuka Lahan}

Bentuk Frasa

Itumani? unuma/ 'buka lahan'

/woresian unuma/ 'pembersihan lahan'

Itana? siri?/'tanah miring'

Bentuk kata

/wayizn/ 'pencangkulan'

/pandekoən/ 'pembajakan'

/maPwayi/ 'mencangkul'

/magogar/ 'terbongkar'

/wayian/ 'dicangkul'

/sisiran/ 'disisir'

/larean/ 'garis'

/waPtun/ 'Berbatu'

/papar/ 'datar'

/pandeko/ 'bajak'

/kawato/ 'kuda'

/wayi/'cangkul'

/toul 'orang'

/pisou/ 'parang'

/kimbo/ 'lobang pipit'

|rombur/ 'gembur'

Bentuk ekspresi linguistik data di atas terdiri atas kata dasar, berafiks dan frasa.

2. Memilih Benih Jagung

/rEyə tumpa? a tatapa?an/ 'benih berasal dari pengasapan'

/tandei timawayan/ 'jagung menyerupai tanaman tawaang'

/tatanəm tandei/ 'benih jagung'

/tinipuPan/ 'tongkol jagung'

lloap/ 'besar'

/wua?nal 'buah'

/rawisnal 'ujung'

Ituurnal 'pangkal' 
Bentuk ekspresi linguistik yang ditemukan berbentuk klausa,frasa, dan kata.

3. Menanam Benih Jagung

/tumanəm tatanəm/ 'Menanam bibit'

/kasiapa lołoon/ 'tidak ada bulan'

/məntəPma lEos samaye tumanəm/ 'makan kenyang-kenyang kalau akan menanam'

/kimbo/ 'lubang'

/larEan/ 'garis yang berlobang'

/mərəy/ 'menutup mata'

/suməpi/ 'panen'

Bentuk ekspresi linguistik yang ditemukan berbentuk frase, kata dan idiom.

4. Pertumbuhan dan Pemeliharaan

/wayian wo tawunan karual 'pencangkulan dan penimbunan kedua'

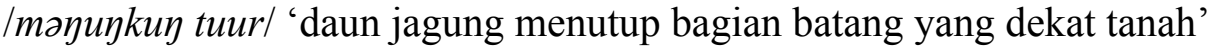

/tandei wuut/ 'jagung busuk'

/mənutal 'jagung bertumbuh seperti duri

/məyatipo?po?/'daun menyerupai kupu-kupu'

/marintzk/ 'daun menjadi kecil dan mulai panjang'

/kawaruan/

/rumuru/; /ruru/ 'pinggir'

/mołułun/ 'ujung pohon jagung sepertinya meruncing'

/mamołok/ 'bunga jagung muncul'

/məтusu?/ 'muncul buah tapi masih kecil'

/marayday/ 'rambut jagung berwarna merah'

/mərəndəm/ 'rambut jagung berwarna hitam'

/waranesapun/ 'menyerupai mata udang'

/məriri?/ 'tumbuhan jagung mulai berwarna kuning'

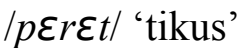

/sombor/ 'muda'

/peramo/ 'sudah kering'

/sapian/ 'dipanen'

Bentuk ekspresi linguistik yang ditemukan berbentuk klausa, frasa, dan kata

5. Panen dan Pascapanen

/rəpuPan/ 'dipatahkan'

/rEwokan/ 'dikumpul'

/tatap?an/ 'tempat pengasapan'

/kuti?on/ 'dikupas'

/tinipu?an/ 'dipipil'

/wataran/ 'dijemur'

/gitiyan/ 'digiling' 
larEən/ 'ditampih memisahkan deda dari beras"'

/tumindin/ 'ditampih untuk memisahkan beras dengan jagung yang ditumbuk tapi masih agak besar’

Bentuk ekspresi linguistik yang ditemukan berbentuk kata yang mendapat afiks.

6. Bentuk Fisik Tanaman Jagung

Berikut ini akan didesktipsikan bentuk fisik tanaman jagung yang terdiri atas

laPmut/'akar'

/tuPul/ 'bagian bawah jagung'

/wuku/ 'ruas jagung'

/rondaina/ 'batang tanaman jagung'

Irainana/ 'daun'

/wotokna/ 'buah'

/rawis/ 'bagian pucuk tanaman jagung'

Beberapa bagian dari bentuk fisik di atas dapat dibagi atas bagian yang lebih kecil atau dapat dikatakan bahwa dari setiap klasifikasi tersebut dapat dibuat klasifikasi yang lebih khusus.Untuk jelasnya dapat dilihat data berikut ini.

a. Iamut/ 'akar'

Akar tanaman jagung terdiri dari

/a?mut rintzk/ 'akar halus'

la?mut səłal 'akar besar'

/ a Pmut rintzk/ adalah akar jagung yang tertutup dengan tanah sedangkan

la Pmut səła/ letaknya berada satu jengkal di atas tanah.Fungsinya agak berbeda, yakni akar kecil menahan tanah dari dalam sedangkan akar besar menguatkan tegaknya batang.

b. Irondaina/ 'batang'

Batang jagung terdiri dari

/tuPur/ 'bagian bawah batang jagung'

/wuku/ 'ruas batang jagung'

/kuli?na rəndaina/ 'kulit yang melekat pada batang jagung'

la?mut səłal 'akar besar yang berada di atas tanah'

c. Irainana/ 'daun jagung'

Apabila diperhatikan daun jagung terdiri dari dua jenis warna, yaitu

/rainanak mata?/'daun hijau'

/rainana riri?/' daun kuning'

/rainana mata?/ adalah daun yang warnanya masih hijau.Artinya jagung masih mengalami pertumbuhan.Apabila daunnya sudah menjadi kuning berarti tinggal menunggu waktu panen. 
d. Iwua?na/ 'buah jagung'

Buah jagung yang sudah berusia empat belas minggu ke atas dikenal dengan istilah /sombor/ 'jagung muda' sampai jagung menjadi /pera/ 'kering' terdiri dari bagian-bagian berikut:

/sawunnal 'rambut jagung'

Ikuti?na/ 'kulit'

/tinipuran/ 'tongkol'

/tandei/ 'biji'

Rambut jagung terdiri atas dua warna, yakni rambut jagung yang menyerupai warna merah dan rambut jagung yang agak kehitam-hitaman.Jagung yang rambutnya /mərayday/ 'mempunyai warna merah' kira-kira berusia sebelas minggu sedangkan jagung yang rambutnya agak kehitaman/mərəndəm/ 'menyerupai warna hitam' kira-kira berusia dua belas minggu.Rambut jagung dalam waktu tertentu sudah bisa dimanfaatkan.Akan tetapi satu hal yang tidak dapat diabaikan bahwa rambut jagung sampai jagung siap dipetik tetap melekat pada buah dan warnanya tetap hitam.Demikian pula, kulit jagung ada yang berwarna hijau da nada yang berwarna kuning.Buah jagung yang masih muda, kulitnya berwarna hijau.Sedangkan, bila sudah siap dipanen kulitnya berwarna kuning.

Bentuk fisik/tandei sombor/ 'jagung muda'

/wołokna kasombor/ 'bunga sangat muda' /sawuyna mərayday/ 'rambut memerah' /kuli?na mata?/ 'kulitnya berwarna hijau' /tandei sombor/ 'pipilan lembut'

Bentuk fisik /tandei tuPa/ 'jagung tua' /wołokna morintak/ 'bunga kecil' /sawuyna marandam/ 'rambut menghitam' /kuti? na riri?/ 'kulitnya berwarna kuning'

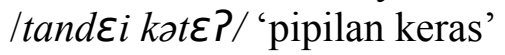

e. Irawisna tandei/ 'pucuk tanaman jagung'

Bagian ujung tanaman jagung akan tampak dengan jelas /wołokna/ bunga jagung. Bunga jagung akan muncul pada usia kira-kira sembilan minggu sejak benih jagung ditanam. Bunga jagung yang tampak pada tanaman jagung adalah bunga jantan.Bunga betina hampir tidak kelihatan.Dalam bahasa Tombulu tidak dibedakan istilah bunga jantan dan bunga betina. Mereka hanya menyebut bunga dengan sebutan /wołokna/ 'bunga'

f. Perubahan Tanaman Jagung Dilihat dari Usia 
/marintək/ 'daun jagung mengecil dan mulai panjang'

/kawaruan/ 'perumbuhan pada masa suburnya'

/məłułun/ 'ujung batang jagung bentuknya meruncing'

/momołok/ 'muncul bunganya'
2-3 minggu

7 minggu

8 minggu

9 minggu

/məmusu?/ 'muncul seperti buah lengkap dengan kulitnya tapi masih kkecil'10 minggu

/mərayday/ 'rambut jagung berwarnah merah'

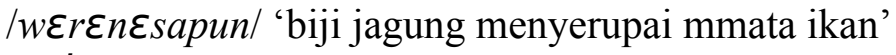

/katanut/ 'biji jangung mulai berisi'

/sombor/ 'jagunng muda'14 minggu

/məriri/ 'jagung mulai berwarna kuning'15 minggu

Ipral 'jagung menjadi kering16 minggu
11 minggu

14 minggu

\section{B. Kearifan Lokaldalam kaitannya dengan Tanaman Pangan Etnis Tombulu}

\section{Gotong Royong/Mapalus}

Mapalus dilakukan setiap anggota masyarakat Tombulu atas motif ingin menunjukkan atau membuktikan persaudaraan/kekeluargaan di antara sesama masyarakat suku ini. Dalam kurun waktu yang lama, sesungguhnya masyarakat sudah merasakan manfaat dari kearifan hidup bersama yang disebutmapalus.

Mapalus dalam praktiknya adalah bentuk kerja sama antarsekelompok orang untuk melakukan pekerjaan tertentu secara bergilir dan saling berbalas, yang akhirnya kepentingan semua anggota kelompok akan terpenuhi. Di dalam konsep kerjasama khas ini, menurut informan yang dieksplorasi lanjut, setiap jasa kerja dari anggota harus atau wajib dibalas oleh anggota kelompok yang lain.

Kelompok yang dibentuk dapat berupa kelompok kerja kecil atau kelompok kerja besar.Jumlahnya bervariasi antara 5, 10, 15 dan seterusnya. Dikenal juga bentuk kerjasama kelompok kecil yang anggotanya terikat dalam hubungan keluarga, namun mereka tidak sama latar belakang pekerjaannya.

Dalam operasionalnya, setiap kelompok Mapalus akan berunding, bersepakat, dan melakukan pekerjaan ladang atau sawah (umumnya ladang) dan kerja kebun tanaman keras milik anggota kelompok secara bergilir. Semua anggota kelompok terpanggil secara sadar, insyaf dan ikhlas akan menaati kewajiban serta tunduk pada kesepakatan kerja, dan urutan giliran kerja yang sudah ditetapkan bersama. Setiap anggota masyarakat akan bersama-sama maju, sekaligus pada situasi tertentu siap pula menanggung ketidakberuntungan secara bersamasama. Hal tersebut berwujud karena filosofi hidup yang mereka anut yang antara lain "tenggelam bersama, terapung bersama" atau. "mundur bersama, maju bersama". 
Seseorang yang berniat akan melakukan kegiatan atau pekerjaan tertentu dapat meminta bantuan tenaga kerja dari anggota masyarakat lainnya. Apalagi untuk melakukan pekerjaan besar, semacam membuka lahan pertanian baru. Dalam kehidupan petani, kegiatan mapalus ditempuh dengan menuntaskan pekerjaan mengikuti tahapan siklus bercocok tanam, seperti membersihkan lahan, menanam hingga panen.

Dapat pula terjadi satu kelompok petani tertentu bekerja bukan pada kepentingan salah satu anggota kelompok. Ini disebut ma? sawang. Hakikinya, ma?sawang adalah pekerjaan yang dilakukan anggota masyarakat dalam posisinya sebagai warga desa dan atasnya dia tidak perlu digaji atau dibalas. Ma? sawang jelas dilakukan atas inisiatif dan kesadaran sebagai warga desa. Biasanya ma?sawang pada acara pesta atau duka.

\section{Posisi Bulan}

Dalam hal menghindari kegagalan ketika melaksanakan kegiatan tanam biasanya petani patuh dan mengikuti jadwal tanam. Petani yang belum berpengalaman biasanya ia akan berkonsultasi dengan petani berpengalaman. Yang berpengalaman biasanya mereka dituakan 'dipandang seperti orang tua yang tahu banyak hal" karena dipercaya mampu membaca tanda-tanda alam. Orang yang dimaksud akan mempergunakan ilmu perbintangan tradisional atau sekadar dengan membandingkannya denganpengalaman hasil tanam yang pernah sekian lama dijalaninya.

Ada metode sederhana penentuan hari menanam yang baik,yaitu dilakukan pada saat hari bulan (menurut kalender bulan) kelipatan tiga yang dimulai pada hari bulan pertama, yaitu pada hari bulan 1, 4, 7, 10 dan seterusnya adalah saat baik untuk menanam jenis tanaman yang berbuah pada bagian-bagian ujung dahan (cengkih, padi, pisang, manggis, rambutan).Kemudian, hari kelipatan tiga yang dihitung dari hari bulan yang kedua, yaitu hari bulan 2, 5, 8, 11 dan seterusnya adalah waktu untuk menanam jenis tanaman yang berbuah ditengah (jagung, durian, pepaya dll); sedang hari bulan kelipatan tiga yang dihitung dari hari bulan ketiga, yaitu hari bulan 3, 6, 9, 12 dan seterusnya adalah waktu yang baik untuk menanam tanaman yang berbuah di akar (ketela, ubi jalar, misalnya).

Pada waktu tanaman berbuah tidak boleh ada pembakaran di ladang atau sawah. Untuk menghindari hamadipergunakan dodeso'sejenis alat perangkap'. Sedangkan, untuk menghadang serangan hama ulat pada keempat sudut lahan diletakkan daun bulu tui (daun bambu lokal). Adapun untuk mengusir hama tikus, biasanya dua batang bulu tui akan digosok-gosok satu dengan lainnya. Dipercaya itu mampu membuat tikus ngilu dan pergi menjauh dari lahan 
pernanian. Kalau masih tidak mempan, dapat diambil daun keladi yang dipotong-potong kecil dan dihamburkan merata di lahan. Ini dipercaya efektif mengusir tikus. Getah batang ini memang tidak disukai tikus karena gatal, juga baunya seperti bau ular yang tak lain merupakan musuh utama yang sangat ditakuti tikus. Sayangnya, aktivitas ini sudah ditinggalkan oleh petani dan mereka lebih memilih untuk mengusir hama dengan membeli obat penangkal di toko-toko pertanian.

Berikut ini, beberapa pengetahuan petani terkait posisi bulan yang dipandang bagus untuk menanam dan dipercayai memberi hasil yang optimal apabila waktu menanam sesuai dengan pengetahuan tersebut.

1) Teluna endo kumawus tumuke? Wo tumanem maksudnya tiga hari setelah melewati bulan purnama (bulan besar) sangat baik untuk menanam.

2) Pate ni lo?lo?en atau bulan mati, maksudnya posisi bulan di sebelah barat (petani mempercayai pada waktu itu sangat baik untuk menanam tanaman apa saja, termasuk tanaman rempah. Keadaan tanaman baik dan pertumbuhannya bagus. Pate ni lo?lo?en telu na endo toro ma?tanem wayaan tataneman.

3) Lo?lo? en weruatau bulan baru; posisi bulan muncul dari sebelah barat dimulai pukul 6 pagi sampai pukul 5 sore. Dipercayai posisi bulan seperti ini sangat tidak baik untuk menanam karena tanaman menjadi kering (mapera). Masyarakat mempercayai juga untuk tidak menyentuh tanaman pada masa tersebut.

4) Lo?lo? en tumuke? atau bulan besar/purnama. Bulan berada di sebelah timur. Petani mempercayai bahwa di masa itu kandungan air pada tanaman banyak.

\section{Posisi Bintang}

Sebagaimana pengetahuan lokal petani berkaitan dengan bulan, demikian pula mereka mempunyai pengetahuan lokal berkaitan dengan bintang sebagai penanda alam.

1) Loloren atau bintang timur mengisyaraatkan waktu sebentar lagi siang, sehingga kebutuhan-kebutuhan untuk bertani sudah harus disiapkan, misalnya bekal yang akan dibawa ke kebun. Loloren juga memberi tanda akan hujan atau panas.

2) We?tes atau bintang tujuh. We? etes yang keluar masuk (kelihatan di langit) selain memberi tanda akan ada hujan atau panas juga akan dapat diketahui tanaman akan berhasil atau tidak. Ketidak berhasilan tanaman, antara lain kerena serangan hama. 
3) Keteluan atau bintang tiga. Kateluan sama dengan we?tes. Bila tampak keluar masuk mengikuti we?tes menandakan akan ada masuk pada musim hujan. Hal ini menjadi was karena hujan yang berlebihan berpengaruh pula pada tanaman.

\section{SIMPULAN DAN SARAN}

\section{A. Simpulan}

Bentuk ekspresi linguistiktanaman jagung dalam bahasa daerah Tombulu bervariasi, ada yang berbentuk kosa kata tunggal, berafiks, frase dan klausa. Tradisi menanam yang merupakan pengetahuan lokal masyarakat Minahasa, khususnya penutur bahasa Tombulu, lebih khusus lagi petani jagung sangat memperhatikan posisi bulan yang dinamai mereka dengan istilah"bulan bagus". Artinya, pekerjaan menanam dapat dilakukan dan hasilnya tanaman yang unggul. Mereka tahu manayang disebut bulan bagus dan juga mana bulan tidak bagus. Bulan yang mereka maksudkan bukan bulan urutan dalam kalender (Januari, Ferbruari, dan seterusnya) tetapi yang mereka maksudkan yaitu posisi bulan yang ada dalam kalender dengan simbol-simbol tertentu. Semuanya itu berupa pengetahuan lokal yang memedomani mereka dalam menata kehidupan sosial.

\section{B. Saran}

Generasi usia produktif berumur di atas 17 tahun hampir melupakan bahasa daerah, terutama berkaitan dengan nama-nama tanaman dan berkaitan dengan jenis tanaman. Anak usia dini sebaiknya diperkenalkan atau diajarkan kembali bahasa daerah yang sifatnya kontekstual, antara lain nama-nama tanaman karena tanaman ini sangat dekat dengan kebutuhan hidup anak. Demikian pula berkaitan dengan kearifan lokal aspek astronomi menanam/tanaman dituruntemurunkan kepada anak-anak.

\section{DAFTAR PUSTAKA}

Danandjaja. 1991. Antropologi Psikologi: Teori, Metode, dan Sejarah Perkembangannya. Jakarta: PT Raja Grafindo Persada.

Duranti, A. 2001. Linguistic Anthropology. Massachussetts Blacwell.

Eilers, F.J. 1995. Berkomunikasi Antara Budaya. Terj.J.Tondowidjojo. Ende: Nusah Indah.

Foley, W.A. 1997. Antropological Linguistics. University of Sidney.

Halliday, M.A.K., dkk. 1992. Bahasa, Konteks, dan Teks: Aspek-aspek Bahasa dalam Pandangan Semiotik Sosial. Yogyakart; Gajah Mada University Press.

Koentjaraningrat. 1990. Pengantar Ilmu Antropologi. Jakarta: Bhineka Cipta

Kridalaksana, H. 2008. Kamus Linguistik Edisi Keempat. Jakarta: Gramedia. 
Masinanbow, E.K.M. 2004.'Teori Kebudayaan dan Ilmu Pengetahuan Budaya dalam Semiotika Budaya'. Penyunting T. Christomy Pengantar Linguistik.\& Untung Yuwono.

Mahsun. 2005. Metode dan Aneka Teknik Analisis Bahasa. Yogyakarta: Duta WacanaUniversity Press.

Sapir, E. 1921.Language: An Introduction to the Study of Speech. New York:Harcourt, Brace and Company.

Sibarani, Robert. 2012. Kearifan Lokal, Hakikat, Peran, dan Metode Tradisi Lisan. Jakarta: Aosiasi Tradisional (ATL)

Spradley,J. P. 1979. The Ethnographic Interview. New York: Holt, Rinehart and Winston.

Sombowadile, P. Dkk. 2012.Kearifan Lokal Kaitannya dengan Pembentukan Watak dan Karakter Bangsa di kabupaten Bolaang Mongondow Selatan. Yogyakarta: Kepel Press.

Sudikan, Y.S. 2001.Metode Penelitian Kebudayaan. Surabaya: Citra Wacana

Tim Peneliti Fakultas Sastra. 1978. Struktur Bahasa Minahasa (Tombulu, Tonsea, Tondano) 